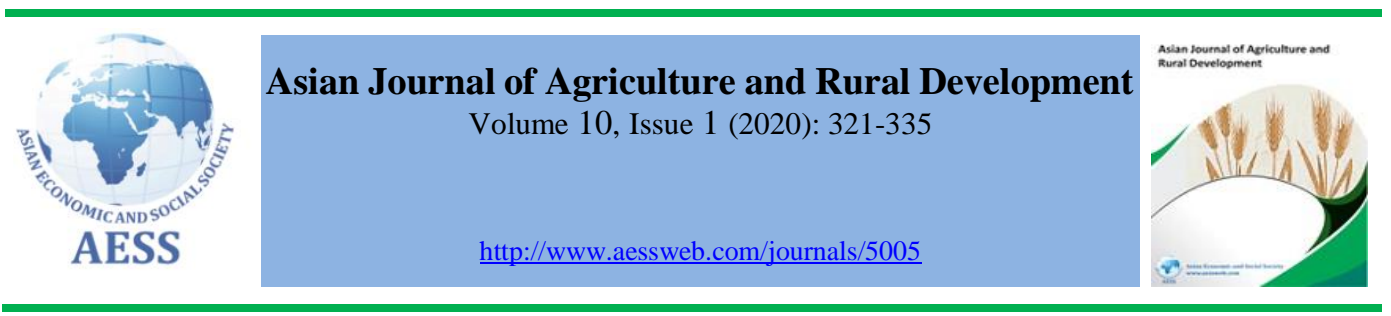

\title{
CONTRACTUAL AGRICULTURE: BETTER PARTNERSHIPS BETWEEN SMALL FARMERS AND THE BUSINESS SECTOR IN THE SULTANATE OF OMAN
}

\author{
Badria Hamed Al Department of Natural Resource Economics, College of Agricultural and \\ Ruqishi ${ }^{a}$ \\ Tarig Gibreel ${ }^{\text {a }}$ \\ Faical Akaichi $^{\text {b }}$ \\ Lokman Zaibet ${ }^{\text {a }}$ \\ Marine Sciences, Sultan Qaboos University, Muscat, Sultanate of Oman \\ Slim Zekri ${ }^{\text {a }}$ \\ ${ }^{b}$ Department of Rural Economy, Environment and Society, Scotland's Rural \\ College, Edinburgh, United Kingdom \\ - $₫$ alruqishi80@yahoo.com (Corresponding author)
}

\begin{abstract}
Received: 28-Feb-2020
2020

\section{Keywords:}

Contract farming,

Stated preferences,

Transaction costs,

Discrete choice,

Mixed logit model,

Latent class model
\end{abstract}

ARTICLE HISTORY:

ABSTRACT
This study aims to elicit the preferences of Omani small-scale vegetable
farmers towards contracting with different emerging and other potential
business partners along with other contract terms. To accomplish this, a
discrete choice experiment was adopted to elicit farmers' preferences
towards different contract models. The choice data was analyzed using
both latent classes as well as mixed logit models and as a result, three
classes were found to best capture the preferences. Class 1 represents $45 \%$
of the respondents who are more likely to adopt the "multipartite
contract" model. This segment is characterized by a high education level,
older age, and smaller family size. The second class represents $31 \%$ of the
sample and tends to adopt an "informal contract" model. This group has a
low experience, larger farm size, and own their private land. The last class
represents $23 \%$ of the observations and is in favour of the "centralized
contract" model. The main characteristics of this class are the low
education level, older age, and medium income. Realizing the farmers'
preferences and their characteristics are certainly important in improving
farmers' participation in the vegetables' market and gearing the policies
towards food security.

Accepted: 04-May-2020

Online Available: 01-Jun-

Contribution/ Originality

The significance of this research stems from the genuine lack of research in Oman related to the role of contractual arrangements involving different governance structures like the form of a true agribusiness and farmer's organization. Secondly, we add a new dimension to the literature by analysing farmers' preferences for different contract models by using a latent class Model and categorizing the choices with the different farmer's characteristics.

DOI: 10.18488/journal.1005/2020.10.1/1005.1.321.335

ISSN (P): 2304-1455/ISSN (E):2224-4433

How to cite: Badria Hamed Al Ruqishi, Tarig Gibreel, Faical Akaichi, Lokman Zaibet, and Slim Zekri (2020). Contractual agriculture: better partnerships between small farmers and the business sector in the Sultanate of Oman. Asian Journal of Agriculture and Rural Development, 10(1), 321-335.

(C) 2020 Asian Economic and Social Society. All rights reserved. 


\section{INTRODUCTION}

According to statistics from the Food and Agriculture Organization of the United Nations (FAO), the Sultanate of Oman relies very heavily on imports to secure roughly $60 \%$ of its vegetable's needs (FAO, 2017). Food prices fluctuations and the need to be secured for food supplies dictate the urgent need of having a robust food security policy. Food security-oriented studies in Oman focused on production efficiency and overlooked the marketing aspect, hence this study has come to close this gap. This research views farmer's ability to grow depending upon better access to high-value chains by participating in different contracts that are patronized by the partnership of different potential business models. These models have emerged as a result of various measures that have been taken by the government to ensure food security by focusing on the potential of vegetable production within Oman. This has resulted in harnessing the private sector by establishing an agribusiness company that could act as an institutional solution to improve the efficiency of the sector. Moreover, small-scale farmers started to operate collectively through farmers' organizations. Over the years, contract farming has been well-thought-out as a system that has great potential for providing an approach to integrate small-scale farmers into export, processing markets and the food security (Dedehouanou et al., 2013; Reardon and Timmer, 2014; Mishra et al., 2018, Vilbert et al., 2019; Gelli, 2015).

It is one of the institutional options that enable small farmers' diversification by enhancing their access to markets, decreasing price risks and transaction costs; contracts that deliver credit, inputs, technology, extension services, and information, aid farmers increase production efficiency; build profit-making culture, and increase income and employment (Birthal et al., 2008; Eaton and Shepherd, 2001; Michelson, 2013; Da Silva and Rankin, 2013). Bellemare and Lim (2018) have viewed the positive effects of contract farming in enhancing small-scale farmers' market participation and its positive impact on their welfare (Wang and Kooten, 2018). Moreover, it enables farmers to upgrade their production value chain and tap into high-quality markets (Demont and Rutsaert, 2017). Several authors also have found that engaging in contract farming has improved small-scale farmers' income and other studies have examined the impact of contract farming on high-value crops like vegetables (see Otsuka et al., 2016 and Wang et al., 2014). It has also been proven that contracts with different patrons such as private companies, processors, cooperatives, and international companies can improve farmers' income (Hazell et al., 2007). Hence, contract farming has been promoted as an institutional innovation and as a critical element for rural development to improve agricultural performance in developing countries.

Consequently, contract farming can be defined as a profitable relationship between a firm and a group of farmers. Grosh (1994) noted that contract farming could act as an agro-institution that can overcome market failure resulting from uncertainty and risk. Most of the studies (Castaneda et al., 2018; Chamberlain and Anseeuw, 2017; Mishra et al., 2016) rarely focused on the complexity of the set-up of such arrangements that involve different instruments like collective organization and agribusiness companies. Different contract models may be perceived differently and these different views depend on the type of contractor, the price, the length of the contract, and by the characteristics of the respondents, Bellemare and Lim (2018). Accordingly, contract farming takes many forms, such as the centralized, informal, and multipartite model (Eaton and Shepherd, 2001). Contract farming models depend on four main components which are the type of contractor, the type of product, the intensity of vertical integration, and the involved stakeholder's number (Bijman, 2008).

Since one size doesn't fit all (Gregory and Chapman, 2002), different potential contracts were tested including an agribusiness company, farmers organization, and retailing companies. However, researchers believe that farmers are still concerned about the contract's nature and hence there is a need to elicit their preferences towards those trade-offs. Since farmers weigh the benefits over the 
costs to maximize their utility, farmers face various kinds of opportunity costs before they decide to engage in a specific contract model. Contract attributes are best analyzed by considering the trade-offs between returns and risks associated with such a mutual relationship. The terms of the contract and its levels were selected based on transaction cost theory (Seng, 2017).

Discrete Choice Experiment (DCE) has been used in many areas to measure preferences for choice alternatives, for instance, DCE has been used to derive farmers' preferences for contract and market channel characteristics (Blandon et al., 2009; Schipmann and Qaim, 2011; Landmann et al., 2018; Fischer and Wollni, 2018; Gelaw et al., 2016; Ochieng et al., 2017; Van den Broeck et al., 2017).

This study uses a DCE that is based on stated preference data. The stated choice method has initially been developed in marketing research and applied in the contract (Lajili et al., 1997). This data is collected from the farm households to analyze farmers' preferences for contract farming that allows controlling the correlation between different attributes for different contract profiles. The primary purpose of the stated preference approach is to assess these models by eliciting farmer's stated preferences towards hypothetical settings (Arouna et al., 2017). This methodology indicates the maximum utility of a particular contract model by separately estimating the preferences of the farmers for the pertinent attributes which characterize the contract model. The stated preference approach is used given the limitation of real contracts on vegetable production in the study area. Hence, the stated choice method offers an excellent opportunity to estimate the demand for new potential contracts.

The objective of this paper is to analyze the farmer's preferences towards different contract structures in the selected study area in the Sultanate of Oman. This research examined different contract options using a latent class model to enable policymakers and the emerging agribusinesses in the vegetable industry to develop a suitable governance structure of contract farming that copes with the business purpose of different farmers groups.

The paper is organized as follows: Section 2 describes the data collection and data analysis including the latent class model. Results are displayed in section 3, and the final section provides the concluding remarks and policy implications.

\section{MATERIALS AND METHODS}

\subsection{Data collection}

Farmers' preferences for which type of contract farming depends on several contract attributes such as the type of contractor, technical assistance, duration of the contract and pricing mechanism (Schlecht and Spiller, 2012) For a better qualitative understanding of which behavioral preferences might affect the valuation of contract characteristics among Omani farmers, focus group discussions were guided by the theory of transaction costs. Farmers in choosing a contract seek to lower the transaction costs associated with information, negotiation, and monitoring (North, 1990). This has helped in evaluating the relevance of specific contract features for farmers and decide how to design the attributes and which levels to include in the Discrete Choice Experiment. Based on farmers' qualitative statements, six attributes were selected. These are shown in Table 1 and vary systematically in their levels: Type of Partner, Cropping decision rights, quality specifications, technical assistance, length of the contract, and the price. The levels corresponding to each attribute of the contract were coded as binary variables except with the price. The level of price specification was considered based on historical data obtained from Al Batinah farmers' organization records. The estimated parameters represent the respondent's preferences concerning the baseline level. Indicated (0) represents the reference/baseline for each level.

A seventh variable "None" (NONE) was also considered to estimate respondents' preferences for the status-quo option. An example of a card where option four is added to give the farmer the 
freedom and avoid the biases of forcing him/her to choose only from the listed options is displayed in Appendix A.

Table 1: Summary of contract attributes and levels

\begin{tabular}{|c|c|c|}
\hline No & Attributes & Levels \\
\hline 1 & Type of Partner & Retailing firm (0), Farmers' organization(1), Processing firm (2) \\
\hline 2 & Cropping Decision Rights & Farmers' organization(0), Trading Firm (1), Individually (2) \\
\hline 3 & Quality specification & $\begin{array}{l}\text { Variable quality requirement (0), Minimum quality requirement } \\
\text { (1), High-quality standards (2) }\end{array}$ \\
\hline 4 & Technical assistance & $\begin{array}{l}\text { Provision of technical assistance by the government ( } 0) \\
\text { Provision of technical assistance by the buyer firm (1) }\end{array}$ \\
\hline 5 & Length of contract & $\begin{array}{l}\text { one year }(12 \text { months })(0) \\
\text { one season }(9 \text { months })(1) \\
\text { two years }(24 \text { months })(2)\end{array}$ \\
\hline 6 & Price & $\begin{array}{l}\text { Market price }(0) \\
7 \% \text { less than the market price }(1) \text {, } \\
7 \% \text { more than the market price }(2) \text {, }\end{array}$ \\
\hline
\end{tabular}

The data were collected interviewing vegetable producers who were randomly selected from an already prepared list of 220 common vegetable small-scale farmers' names obtained from the Ministry of Agriculture and Fisheries, whose farms with a holding size of fewer than five hectares. In total 160 farmers were surveyed and interviewed between May and July 2019 in 8 provinces (wilayat) in Al Dakiliah and Batinah Governorates of the Sultanate of Oman, considered as the principal vegetable production areas in the country, using a structured questionnaire comprising two parts. The first part was used to collect the socio-economic and demographic characteristics of producers. The second part focuses on the choice experiment. To examine the farmer's preferences towards different contract models, Ngene software was used to ensure the main effect of interaction and to generate the efficient total number of choices set combinations. An efficient design of eight choice sets was generated and broken into three blocks.

Making these cards readable to the farmers with clear levels and attributes, the choice cards are translated into the Arabic language. Each farmer was asked to complete 8 choice sets and asked to choose one option out of the three choices presented in every card and a fourth opt-out alternative.

\subsection{Data analysis}

The data collected were analysed within a random utility framework (McFadden, 1974). Thus, an individual $n$ presented with $j$ alternatives at a choice occasion $t$ is expected to choose the alternative that maximizes his/her utility. Following Lancaster's concept that any product is a bundle of attributes (Lancaster, 1966), the utility that an individual $n$ derives from the consumption of a product is assumed to be equal to the sum of his/her marginal utility for each of the product's attributes. Therefore, what a farmer derives from a contract farming package is expected to be equivalent to the summation of the marginal utilities for each of its attributes. Therefore, the potential value of utility of an individual $i$ 's associated with a contract farming $j$ is defined as $U_{i j t}$, which is particular for each $j^{\text {th }}$ contract farming alternative a $t^{\text {th }}$ choice occasion. It can be written as a function of two components: an observable systematic component $\left(V_{i j t}\right)$ and a random component $\left(\varepsilon_{i j t}\right)$, which encompasses the unobservable part. Thus, the utility function can be written as follows:

$$
U_{i j t}=V_{i j t}+\varepsilon_{i j t}
$$

Where, $V_{i j t}$ represents the systematic utility and $\varepsilon_{i j t}$ is assumed to be independent and identically distributed for all options in each choice set. The systematic utility $\left(V_{i j t}\right)$, expressed as a 
generalized regression function (Ben-Akiva and Boccara, 1995) as a function of various explanatory variables can be written as:

$$
U_{i j t}=\beta X_{i j t}+\varepsilon_{i j t}
$$

$U_{i j t}$ can be expressed by $K$ attributes $X_{i j t}$ that are assessed by parameters specific to respondent choice $\boldsymbol{\beta}_{i j t}$ that is not observable and unknown utility parameter by the concerned researchers. Where $\beta$ denotes the $K \times 1$ vector of unknown marginal utilities that are associated with the Farming contract attributes $X_{i j t}$.

The individual preferences that are not observable are to be considered in the stochastic component $\varepsilon_{i j t}$, assuming an independently and identically distributed extreme value distribution. Thereby, $\boldsymbol{\beta}$ denotes the vector of unknown parameters that are associated with the farming contract attributes $\mathrm{X}_{i j t}$. Individuals' preferences heterogeneity is tested by a model called the Mixed Logit Model which was suggested by Train (1998). In the Mixed Logit Model, the independence of Irrelevant Alternatives is relaxed and the following formula defines the conditional choice probability that individuals choose an alternative $\mathrm{j}$ at a choice occasion $\mathrm{t}$ as:

$$
p(j \mid X i t, \beta)=\prod_{t=1}^{T}\left[\frac{\exp \left(\mathrm{X}^{\prime} i t, j \beta q\right)}{\sum_{k=1}^{J} \exp \left(\beta^{\prime \mathrm{X}^{\prime}} i k t\right)}\right]
$$

The unconditional choice probability is the expected value of the logit probability integrated over all possible values of $\boldsymbol{\beta}$ and weighted by the density of:

$$
p(j \mid X i t, \Omega)=\int_{\beta} p(j, X i t,) f(\beta \mid \Omega) \mathrm{d} \beta
$$

As the expression in the above formula does not have one solution, then simulation methods are created to resolve this issue. The choice probability has been calculated for each draw. Maximum Likelihood procedures have been used to estimate the simulated log-likelihood (SLL) and are calculated as:

$$
S L L=\sum_{i=1}^{I} \sum_{t=1}^{T} \ln \left(\frac{1}{R} \sum_{R=1}^{R} \frac{\exp \left(\beta^{\prime} i X i j t\right)}{\sum_{k=1}^{j} \exp \left(\beta^{\prime} i X i j t\right)}\right)
$$

Train (2009) has created a new approach called conditional distributions to calculate individualspecific distributions. The main reason behind this computation is to obtain sufficient information on the likely position of each respondent. However, using the conditional distributions approach to evaluate the heterogeneity of respondents" preferences is of limited practical use. The estimation of the Mixed Logit Model has allowed examining that respondents' attitudes are highly heterogeneous. Although this model does not explain the source of the heterogeneity it does control it and considers the attributes variation across respondents.

Therefore, the focus has been shifted to different alternatives termed latent levels (LCM) to analyze discrete choice analysis and explain the heterogeneity, Greene and Hensher (2003) LCM captures the source of heterogeneity in the individual's preferences by assuming a homogenous preferences pattern within distinct groups. This model is powerful for decision making and policy-relevant analysis.

The log-likelihood for respondents in the LCM for discrete choice analysis can be described as:

$$
\ln l=\sum_{i=1}^{N} \ln \left[\sum_{q=1}^{Q} H i q\left(\prod_{t=1}^{T i} \operatorname{Pit} \mid q(i)\right)\right]
$$


Where $H_{i q}$ denotes prior probability for class q for individual i. for this study, the form of the prior probability is a multinomial logit

$H i q=\frac{\operatorname{Exp}\left(\mathrm{zi}^{\prime} \theta \mathrm{q}\right)}{\sum_{q=1}^{Q} \exp \left(z^{\prime} i \theta q\right)}, q=1, \ldots \ldots, Q, \theta Q=0$

Where $Z_{i}$ refers to a set of observable characteristics (e,g socio-demographics such as gender, age, and income) that enter the model for class membership.

$P_{i t q}$ is the chosen probability that individual $i$, conditional to belonging to class $\mathrm{q}(\mathrm{q}=1, \ldots \mathrm{q})$ chooses alternative $i$ from a particular set $j$, comprised of $j$ alternatives, in a particular choice occasion $t$, and is represented as:

$$
p i t \mid q(j)=\frac{\exp \left(\mathrm{X}^{\prime} i t, j \beta q\right)}{\sum_{j=1}^{J} \exp \left(\mathrm{X}^{\prime} i t, j \beta q\right)}
$$

Then beta regression analysis uses the computed respondent specific estimates to profile the members of each class. Two criteria, which are the Consistent Akaike information Criterion (CAIC) and the Bayesian Information Criterion (BIC), are used to determine the number of classes.

\section{RESULTS AND DISCUSSION}

The Mixed Logit Model was estimated by using modified Latin Hypercube Sampling draws along with 1200 simulations, considering repeated choice situations. All the estimations were conducted using the R-studio software and Stata software. The results displayed in Table 2 show the latent class model with 3 classes, fit the data better than the conditional logit based on the CAIC and BIC Values;

Table 2: Information on the converged latent segment models

\begin{tabular}{lccccc}
\hline $\begin{array}{l}\text { Number } \\
\text { of Classes }\end{array}$ & $\begin{array}{c}\text { Log likelihood } \\
\text { at convergence }(\mathbf{L} \mathbf{L})\end{array}$ & $\begin{array}{c}\text { Number } \\
\text { of parameters }(\mathbf{P})\end{array}$ & $\begin{array}{c}\text { Number } \\
\text { of respondents }(\mathbf{N})\end{array}$ & CAIC & BIC \\
\hline 2 & -1097.9 & 31 & 116 & 2374.16 & 2343.16 \\
3 & -1052.0 & 50 & 116 & 2392.48 & 2342.48 \\
4 & -1036.3 & 69 & 116 & 2469.60 & 2400.60 \\
5 & -1005.7 & 88 & 116 & 2517.72 & 2429.72 \\
\hline
\end{tabular}

CAIC (Consistent Akaike Information Criterion) is calculated using: $-2 * \mathrm{LL}+(\ln (\mathrm{N})+1) * \mathrm{P}$ BIC (Bayesian Information Criterion) is calculated using: $-2 * \mathrm{LL}+\ln (\mathrm{N}) * \mathrm{P}$

Results derived from the estimation of the Mixed Logit Model and the LCM are presented in Table 3. The results indicate that the estimated marginal utilities are significant. The positive sign of the coefficient "Opt-out option" suggests a general preference for the opt-out alternative. It is crucial to recall those respondents who chose "none" for all choices presented have been excluded. Most of the standard deviation parameters, which show how the valuation of the entire sample spreads around the estimated means are significant, indicating that the preferences heterogeneity is maintained among the sampled farmers. The estimated $7 \%$ less than the market price coefficient statistically significant and is negative, indicating that respondents prefer to choose price running the market rather than the market price, other attributes constant.

\subsection{Types of partner}

To improve the efficiency of the agricultural sector, the Omani government has decided to establish an agribusiness company as an institutional solution to link farmers with the market and to ensure 
the food security (Ministry of Agriculture and Fisheries, 2019), it is targeting large scale farming contracts (Al-Abdali, 2019). Nevertheless, small-scale farmers can integrate with large scale farming if they operate collectively through farmers' organizations. However, the forming of such an organization in Oman is not supported by a legal setting. It is possible to be established as nonprofit organizations, and this legal form constrains it to function as a profit and commercial entity, (FAO and SQU, 2018).

The results from the Mixed Logit Model, displayed in Table 3 corroborates the existing legislative status of the farmer's organization in Oman where that respondents are indifferent about the type of partner to contract with the farmer's organization or the trading firm. Nevertheless, respondents in class 1 and class 2 shows that they are less likely to favor a farmer's organization compared to the trading firm. This result is expected, given that the farmer's organization can lower transaction costs (Andersson et al., 2015).

Unsurprisingly, the coefficient of the variable "processing firm" is negative and significant at $1 \%$ for class 1 , which means that vegetable farmers are more likely to make a contract with retailing firms such as supermarkets and hypermarkets instead of processing firm. It could be attributed to the fact that farmers are familiar with the traders than with the processing firm. Moreover, it could be explained by the farmer's perception that the processing firms target large scale farms by which would harm the small scale business farms. Nevertheless, farmers in class 2 are indifferent to adopt processing firms concerning the retailing partner, but class 3 is more likely to adopt the processing firm shows a significant level of $5 \%$ with a coefficient of 0.713 .

\subsection{Cropping decision rights}

The agricultural commodity market is described by speculative behavior (Tadesse and Guttormsen, 2011). It was expected that farmers would prefer the firm to take the lead of cropping decision, to avoid unpredicted price fluctuations and the naïve cropping imitation. However, it was found that overall, farmers are more likely to prefer individual decisions. The results of MLM displayed in table 3 show that farmers are more likely to decide individually upon the crop's type instead of giving the lead to the farmer's organization. Moreover, farmers are indifferent to the trading firm and farmer's organization to decide for them the crop's type.

Farmer's organization is the reference line in eliciting the cropping decision to compare the farmer's preferences concerning deciding upon the crop type by other partners such as the Subsidiary trading company or deciding individually. With the latent class model, it shows a significant sign of $1 \%$ for class 1 that is more likely to adopt the decision of trading firm concerning farmer's organization. Class 2 and 3 are indifferent to their preferences upon the decision of cropping. However, with the latent class model, it showed that class 3 are more likely to adopt the individual decision compared with class 1 , while class 2 is the least class that prefers to go with the individual decision in cropping.

\subsection{Quality specification}

Quality standards play a major factor in sustaining a healthy contractual relationship (Dolan et al., 2000; Berdegue et al., 2005). The prior quality specification is crucial to reduce the pertinent uncertainty related to the demand of the buying firm which results in lower transaction costs (Goodhue, 2011). Mixed Logit Model in table 3 shows indifferent preferences over the contract that requires low-quality specification and a contract that specifies the variable quality as a variable. However, the preferences with high-quality specifications over the variable quality one are highly significant. With latent class Model, positive and significant results at 5\% presented reveal that farmers in class 2 are more likely to prefer low quality over the variable quality specification and farmers in class 1 prefer more variable quality specifications. 
In class 2 and 3, they prefer more high-quality specifications with respect to the variable requirement. This shows that high-quality standards are important for vegetable farmers especially farmers in class three compared with class 2 . On the contrary, farmers in class 1 are indifferent about the high-quality standard.

\subsection{Technical assistance provision}

Farmers should have sufficient knowledge and know-how to meet food quality specifications and enhance productivity. Within the Omani context, farmers can obtain technical assistance from the government through the Ministry of Agriculture and Fisheries. The statistical analysis has shown a negative coefficient sign with respect to the technical assistance provided by the government compared to the buyer firm and this implies that farmers prefer more the assistance to be provided by the firm instead of the government especially class 1 and class 3 . Whereas, class 2 is indifferent about the source of technical assistance provision. The tendency to favor the provision of technical assistance by the contracted firms rather than the government can be attributed to the professional quality approach set by the firm to be followed and found that this professionalism doesn't exist with the government (Bellemare, 2010).

According to Masakure and Henson (2005), the technical assistance provided by the buying firm incentivizes farmers to enhance their farm performance and farmers' accumulative farming experience.

\subsection{Duration of the contract}

Overall, $76 \%$ of farmers are indifferent between the three proposed durations of contract. This implies that farmers prefer the short-duration contract of 9 months compared to 12 months (the baseline). This tendency towards shorter contracts could be attributed to the fact of farmer's uncertainty and risk aversion and could be also explained by the climate adaptability to grow vegetables during one season only. Short contracts allow the farmers to abrogate the contract if the partner does not adhere to an agreement. At the same time, other farmers are indifferent about the length of the contract. The variable "contract of 9 months" coefficient is significant for latent class 3 where the marginal effects are estimated at 0.970 and represent only $23 \%$ of sampled farmers.

The other level of contract length "contract 24 months" in the Mixed logit model reveals farmer's indifferences about this contract with respect to "contract of 12 months". This confirms the preferences by latent class model, the three classes are indifferent about the length of the contract of 24 months with respect to 12 months.

\subsection{Price}

Price is considered as the first term discussed between parties in contracts( Hernández et al., 2007). The coefficient of "7\% less than market price" is significant and negative. Not surprising, this revealed that contracts with market prices increase the probability for farmers to adopt a contract. Market prices guarantee the market for their production (Michelson, 2012). Besides, the market price reduces the uncertainty associated with fluctuated prices. The same attribute's coefficient is negative and significant with latent class 2 that reveals the preference of market price. The level of $7 \%$ more than market price shows a coefficient is insignificant with the Latent class model and Mixed Logit Model, which indicates their indifferences about this level. 
Table 3: Estimated farmers' preferences

\begin{tabular}{|c|c|c|c|c|c|}
\hline \multirow[b]{2}{*}{ Variables } & \multicolumn{2}{|c|}{$\begin{array}{l}\text { Mixed logit model } \\
\text { (MLM) }\end{array}$} & \multicolumn{3}{|c|}{ Latent class model (LCM) } \\
\hline & Mean & $\begin{array}{c}\text { standard } \\
\text { deviations }\end{array}$ & Class 1 & Class 2 & Class 3 \\
\hline Farmer organization & 0.083 & -- & -0.012 & -0.362 & 0.258 \\
\hline Processing firm & $-0.492 * *$ & $1.109 * * *$ & $-0.812 * * *$ & 0.008 & $0.713 * *$ \\
\hline $\begin{array}{l}\text { Cropping decision by a } \\
\text { Trading firm }\end{array}$ & -0.091 & $1.142 * * *$ & $0.758 * * *$ & 0.222 & 0.030 \\
\hline Individual cropping decision & $0.433 *$ & $0.876 * * *$ & 0.064 & -0.262 & 0.367 \\
\hline Low quality & 0.143 & $0.846^{* *}$ & -0.423 & $0.852 * *$ & -0.662 \\
\hline High quality & $0.589 * * *$ & $0.648 * * *$ & 0.370 & $0.409^{*}$ & $0.824 * * *$ \\
\hline $\begin{array}{l}\text { Technical assistance by } \\
\text { government }\end{array}$ & -0.209 & -- & $-0.558 * *$ & 0.201 & $-0.730 * * *$ \\
\hline Contract 9 months & 0.098 & -- & 0.390 & 0.122 & $0.970 * *$ \\
\hline Contract 24 months & -0.086 & -- & 0.117 & 0.144 & 0.307 \\
\hline $7 \%$ less than market price & $-0.538 * * *$ & -- & -0.333 & $-0.572 * *$ & -0.506 \\
\hline $\begin{array}{l}7 \% \text { more than the market } \\
\text { price }\end{array}$ & -0.096 & -- & 0.300 & 0.046 & -0.758 \\
\hline Opt-out option & $3.268 * * *$ & $12.147 * * *$ & $1.545^{* * *}$ & $-1.665^{* * *}$ & $-1.985 * *$ \\
\hline Class shares & 1 & & 0.45 & 0.31 & 0.23 \\
\hline
\end{tabular}

$* * *, * *$, and $*$ denotes significant at $1 \%, 5 \%$, and $10 \%$ level of significance respectively.

Table 4: Regression results based on marginal effects

\begin{tabular}{|c|c|c|c|c|c|c|}
\hline \multirow{2}{*}{ Variables } & \multicolumn{2}{|c|}{ Class 1} & \multicolumn{2}{|c|}{ Class 2} & \multicolumn{2}{|c|}{ Class 3} \\
\hline & Coef. & Std.Err & Coef. & Std.Err & Coef. & Std.Err \\
\hline$\overline{\text { Region }}$ & $-1.937 * * *$ & 0.049 & $0.461 * * *$ & 0.093 & $10.4^{* * *}$ & 0.324 \\
\hline Gender & $-0.146^{* *}$ & 0.067 & -0.046 & 0.107 & 0.006 & 0.008 \\
\hline Low education & $0.623 * * *$ & 0.126 & $-0.908 * * *$ & 0.136 & $0.313^{* * *}$ & 0.038 \\
\hline High education & $0.706^{* * *}$ & 0.057 & $0.371 * * *$ & 0.097 & $-1.681 * * *$ & 0.008 \\
\hline Age & $0.004 *$ & 0.002 & $0.008 * * *$ & 0.003 & $0.001 *$ & 0.000 \\
\hline Family size & $-0.012 *$ & 0.007 & $-0.033 * * *$ & 0.011 & $-0.002 * *$ & 0.001 \\
\hline Main job & $0.154 * * *$ & 0.045 & $0.321 * * *$ & 0.069 & 0.015 & 0.011 \\
\hline Low income & $1.093 * * *$ & 0.057 & 0.015 & 0.099 & $-1.983 * * *$ & 0.012 \\
\hline High income & $-0.273 * * *$ & 0.058 & $0.204^{*}$ & 0.118 & -0.005 & 0.011 \\
\hline Marketing experience & $-0.004 * *$ & 0.002 & $-0.008 * * *$ & 0.003 & 0.000 & 0.000 \\
\hline Land ownership & 0.068 & 0.053 & 0.085 & 0.098 & $-0.015^{*}$ & 0.008 \\
\hline Medium operated land & -0.051 & -0.850 & -0.017 & -0.170 & -0.005 & -0.690 \\
\hline Large operated land & $0.101 *$ & 1.880 & $0.209 * * *$ & 2.440 & 0.015 & 1.370 \\
\hline Inherited land & $0.138 * *$ & 2.110 & 0.109 & 1.030 & 0.002 & 0.180 \\
\hline Rented land & $0.393 * * *$ & 0.105 & $0.669 * * *$ & 0.178 & 0.033 & 0.025 \\
\hline Shared land & $0.371 * * *$ & 0.104 & $0.589 * * *$ & 0.202 & 0.029 & 0.022 \\
\hline Government land & $0.613 * * *$ & 14.280 & $-0.128 *$ & -1.790 & $-0.715 * * *$ & -80.110 \\
\hline Low cultivated vegetables & 0.038 & 0.044 & 0.014 & 0.074 & -0.006 & 0.008 \\
\hline High cultivated vegetables & 0.011 & 0.077 & -0.057 & 0.160 & -0.035 & 0.017 \\
\hline Constant & -0.168 & 0.171 & $-1.401 * * *$ & 0.295 & -9.642 & 0.327 \\
\hline Class share & \multicolumn{2}{|c|}{0.45} & \multicolumn{2}{|c|}{0.31} & \multicolumn{2}{|c|}{0.23} \\
\hline Log-likelihood final & \multicolumn{2}{|c|}{221.52} & \multicolumn{2}{|c|}{141.26} & \multicolumn{2}{|c|}{833.42} \\
\hline Numberof observation & \multicolumn{2}{|c|}{111} & \multicolumn{2}{|c|}{111} & \multicolumn{2}{|c|}{111} \\
\hline Wald test value & \multicolumn{2}{|c|}{11763.3} & \multicolumn{2}{|c|}{243.88} & \multicolumn{2}{|c|}{729812.5} \\
\hline $\mathrm{P}$-value & \multicolumn{2}{|c|}{$<0.01$} & \multicolumn{2}{|c|}{$<0.01$} & \multicolumn{2}{|c|}{$<0.01$} \\
\hline
\end{tabular}

$* * *, * *$, and $*$ denotes significant at $1 \%, 5 \%$, and $10 \%$ level of significance respectively. 


\subsection{Heterogeneity}

To gain more information about the hypothesis of this research that one size of the contract does not fit all, it was necessary to identify different segments with similar preferences. The estimated standard deviations are significant and indicating the presence of heterogeneity which corroborates the hypothesis of this research. Moreover, identifying the segments of farmers with homogeneous preferences would help to efficiently target them using strategies tailored to their specific needs. Hence, the abovementioned three Latent class models described how farmers' responses varied across different segments. In this section, the features that describe the preferences of those groups are profiled and labeled according to the characteristics of the farmers by using the results of Beta Regressions displayed in table 4. The variables are described in Appendix B. Beta Regression analysis is used to determine the relationship between the probability of a farmer to belong to one of the three classes and the independent variables considered in the regression. This can help design and tailor the policy that fits the needs of the members of each class and identify the contract model type which fits the group. Each described class is provided with a title that is compatible with the contract type. The Probability Scale of the socio-demographic variables presented in Table 4 helps understand how different classes vary against these indicators and what are the socio-demographic characteristics of each class.

Table 5: Summary of the preferred contracts by the members of each class

\begin{tabular}{lccc}
\hline Attributes & Class 1 & Class 2 & Class 3 \\
"Multipartite model" & "Informal model" & "Centralized model" \\
\hline Type of Partner & Retailing Firms & indifferent & Processing firm \\
Cropping Decision & Trading firm & Indifferent & Indifferent \\
Quality specification & Indifferent & low quality & High quality \\
Technical assistance & Trading firm & Indifferent & Trading firm \\
Length of contract & Indifferent & Indifferent & 9 months \\
Price & Indifferent & Market price & Indifferent \\
\hline
\end{tabular}

\section{Class 1 "Multipartite Model"}

This class represents $45 \%$ of the entire respondents, and It is the class whose members are indifferent about farmers' organization. They are also unwilling to contract with processing firms and prefer retailing firms instead. To cope with uncertainty and to reduce transaction costs, farmers in this class are willing to be led by the trading firm in deciding upon the crop types. This group is also indifferent about the quality specification. This class is more inclined towards seeking the technical assistance provided by the buying firm. This class preferences match with the attributes of the multipartite model in terms of the needed coordination and the joint venture business model. The results displayed in Table 5 show that the Dakhiliya region farmers are more in class 1 compared to the Batinah farmers. Moreover, in this class older people, large family size, and those whose main job is farming are presented comparing with other demographic segments. In addition, this class indicates that those of low income are well ahead of those characterized as high income. Also, this class includes more of those of high marketing experience and those who own highly operated farms. Farmers who attained land from the government and who inherited their lands are more in this class.

\section{Class 2 "Informal contract model"}

This class represents $31 \%$ of the respondents. This type of contract is characterized by its transitory nature where the farmers are not usually engaged in directed farming.

It is characterized by their indifferent preferences between retailing firms, the farmers' organization and the processing firm. They are also indifferent about the decision of selecting the crop. Farmers in this class prefer low-quality standards. With regards to the provided technical assistance, results in Table 3 show that farmers are indifferent about it whether to be provided by the government or the buying firm. The length of the contract is also not crucial to the farmers as the price. 
Unsurprisingly, Farmers prefer the "market price" more than the 7\% lower price". The class preferences match the informal contract model type. From Table 4, it can be noticed that this member of class 2 is more likely to be located in the Batinah region compared to Dakhliah. The same segment is more likely to have highly educated farmers and less likely to have a large family size. In this segment, the farmers whose main job is farming is proportionally higher compared to other classes. The farm is larger compared to other classes' farms. Farm ownership indicates that this group has less governmental land and more rented or shared private land. The marketing experience of this group shows the negative value and this indicates the low experience the farmers have in terms of several years.

\section{Class 3 "Centralized contracting model”}

This model main characteristics are directed contract farming where there is a commitment from the Private corporate sector to provide technical assistance to farmers to meet the high-quality standards. This group represents $23 \%$ of the observations. Farmers are indifferent about contracting with the farmers' organization or the retailing firm. However, the segment has stronger preferences to contract with the processing firm. The members of this class are indifferent about the production decision. The segment also prefers the high-quality standards significantly with respect to the variable quality specification. The technical assistance provided by the buying firm is much more preferred compared to the one provided by the government. The members of this segment prefer the shortest contract of 9 months. These class preferences attribute match more with the centralized contracting model type, quality specification and technical assistance. Farmers of this class tend to have low education levels, old age, and medium-income and tend to own their land.

\section{CONCLUSIONS}

Contract farming is important to solve farmers' marketing problems in Oman. However, there exists no "one size fits all" contract; farmers exhibit different preferences for partners' types and terms of the contract. This study showed that $76 \%$ of the farmers prefer contracting with retailing firms and farmer organizations while $24 \%$ of farmers believe that the centralized contract model is their choice and the processing firm which is supported by the government is the main partner for them. Policymakers should ensure prospected policies are matched with the farmer's preferences in setting legal profit-oriented producers' organizations.

Funding: This study received a financial support.
Competing Interests: The authors declared that they have no conflict of interests.
Contributors/Acknowledgement: This project is supported by the internal grant (IG/AGR/ECON/18/01)
and from Sultan Qaboos University bench fees given to PhDs students. This work also would not have
been finalized without the assistance of Dr. Faical Akaichi from Scotland's Rural College at Edinburgh
University.
Views and opinions expressed in this study are the views and opinions of the authors, Asian Journal of
Agriculture and Rural Development shall not be responsible or answerable for any loss, damage or
liability, etc. caused in relation to/arising out of the use of the content.

\section{References}

Andersson, C. I., Change, C. G., Rao, E. J., \& Qaim, M. (2015). Following up on smallholder farmers and supermarkets in Kenya. American Journal of Agricultural Economics, 97(4), 1247-1266. http://doi.org/10.1093/ajae/aav006.

Arouna, A., Adegbola, P. Y., Zossou, R. C., Babatunde, R., \& Diagne, A. (2017). Contract farming preferences of smallholder rice producers in Benin: a stated choice model using mixed logit. Tropicultura, 35(4), 180-191.

Al-Abdali, S. (2019). April 17, Sultanate of Oman, Muscat, food security company. Personal interview about the farming contract. 
Bellemare, M. F., \& Bloem, J. R. (2018). Does contract farming improve welfare? A review. World Development, 112, 259-271.

Bellemare, M. F. (2010). Agricultural extension and imperfect supervision in contract farming: evidence from Madagascar. Agricultural Economics, 41, 507-517. http://doi.org/10.1111/j.1574-0862.2010.00462.x.

Ben-Akiva, M., \& Boccara, B. (1995). Discrete choice models with latent choice sets. International Journal of Research in Marketing, 12(1), 9-24. http://doi.org/10.1016/0167-8116(95)00002-j

Berdegué, J. A., Balsevich, F., Flores, L., \& Reardon, T. (2005). Central American supermarkets' private standards of quality and safety in procurement of fresh fruits and vegetables. Food Policy, 30, 254-269. http://doi.org/10.1016/j.foodpol.2005.05.003.

Blandon, J., Henson, S., \& Cranfield, J. (2009). Small-scale farmer participation in new agri-food supply chains: Case of the supermarket supply chain for fruit and vegetables in Honduras. Journal of International Development: The Journal of the Development Studies Association, 21(7), 971-984.

Bijman, J. (2008). Contract farming in developing countries. An overview. Wageningen: Wageningen University. The Netherlands.

Birthal, P. S., Jha, A. K., Tiongco, M. M., \& Narrod, C. (2008). Improving farm-to-market linkages through contract farming a case study of smallholder dairying in India. IFPRI Discussion Paper 00814 http://www.environmentportal.in/files/IFPRIDP00814.pdf.

Chamberlain, W. O., \& Anseeuw, W. (2017). Contract farming as part of a multi-instrument inclusive business structure: a theoretical analysis. Agrekon, 56(2), 158-172. http://doi.org/10.1080/03031853.2017.1297725.

Castaneda, A., Doan, D., Newhouse, D., Nguyen, M. C., Uematsu, H., \& Azevedo, J. P. (2018). A new profile of the global poor. World Development, 101, 250-267. http://doi.org/10.1016/j.worlddev.2017.08.002

Da Silva, C. A., \& Rankin, M. (2013). Contract farming for inclusive market access. FAO, Rome, Italy. Page 23.

Dedehouanou, S. F. A., Swinnen, J., \& Maertens, M. (2013). Does contracting make farmers happy? Evidence from Senegal. Review of Income and Wealth, 59, 138-160.

Demont, M., \& Rutsaert, P. (2017). Restructuring the Vietnamese rice sector: towards increasing sustainability. Sustainability, 9(2), 1-15. http://doi.org/10.3390/su9020325.

Dolan, C., \& Humphrey, J. (2000). governance and trade in fresh vegetables: the impact of UK supermarkets on the African horticulture industry. Journal of Development Studies, 37, 147176.

Eaton, C., \& Shepherd, A. W. (2001). Contract farming. Partnerships for growth. Economics. Journal of African Economies, 3(2), 231-261.

Fischer, S., \& Wollni, M. (2018). The role of farmers' trust, risk and time preferences for contract choices: Experimental evidence from the Ghanaian pineapple sector. Food policy, 81, 67-81.

Food and Agriculture organization and Sultan Qaboos University (2018). Strengthening national capacities of producer organizations in the sultanate of Oman. Muscat. http://www.fao.org/3/ca8795en/CA8795EN.pdf.

Food and Agriculture Organization of the United Nations. (2017). FAOSTATA statistical database. http://www.fao.org/faostat/en/\#data/FBS.

Gelli, A., Hawkes, C., Donovan, J., Harris, J., Allen, S., de Brauw, A., Henson, S., Johnson, N. Garrett, J., \& Ryckembusch, D. (2015). Value chains for Nutrition. Discussion Paper 01413. International Food Policy Research Institute.

Goodhue, R. E. (2011). Food quality: the design of incentive contracts. Annual Review of Resource Economics, 3, 119-149.

Gregory, G., \& Chapman, C. (2002). Differentiated instructional strategies: One size doesn't fit all. Thousand Oaks, Calif: Corwin Press.

Gelaw, F., Speelman, S., \& Van Huylenbroeck, G. (2016). Farmers' marketing preferences in local coffee markets: Evidence from a choice experiment in Ethiopia. Food policy, 61, 92-102. 
Greene, W. H., \& Hensher, D. A. (2003). A latent class model for discrete choice analysis: contrasts with mixed logit. Transportation Research Part B: Methodological, 37(8), 681698.

Grosh, B. (1994). Contract farming in Africa: an application of the new institutional economics. Journal of African Economies, 3(2), 231-261.

Hazell, P. B., Poulton, C., Wiggins, S., \& Dorward, A. (2007). The future of small farms for poverty reduction and growth (Vol. 42). Intl Food Policy Res Inst.

Hernández, R., Reardon, T., \& Berdegué, J. (2007). Supermarkets, wholesalers, and tomato growers in Guatemala. Agricultural Economics 36(3), 281-290. http://doi.org/10.1111/j.1574- 0862.2007.00206.x.

Lajili, K., Barry, P. J., Sonka, S. T., \& Mahoney, J. T. (1997). Farmers' preferences for crop contracts. Journal of Agricultural and Resource Economics, 22(2), 264-280.

Lancaster, K. J. (1966). A new approach to consumer theory. Journal of Political Economy, 74(2), 132-157.

Landmann, D., Feil, J. H., Lagerkvist, C. J., \& Otter, V. (2018). Designing capacity development activities of small-scale farmers in developing countries based on discrete choice experiments (No. 277738). International Association of Agricultural Economists (pp.7-10).

Masakure, O., \& Henson, S. (2005). Why do small-scale producers choose to produce under contract? lessons from nontraditional vegetable exports from Zimbabwe. World Development, 33(10), 1721-1733.

McFadden, D. (1974). Conditional logit analysis of qualitative choice behavior. Frontiers in Econometrics, 105-142.

Michelson, H. (2013). Small farmers, NGOs, and a Walmart world: Welfare effects of supermarkets operating in Nicaragua. American Journal of Agricultural Economics, 95(3), 628-649.

Michelson, H., Reardon, T., \& Perez, F., 2012. Small farmers and big retail: Trade-offs of supplying supermarkets in Nicaragua. World Development, 40(2), 342-354. http://doi.org/10.1016/j.worlddev.2011.07.013.

Ministry of Agriculture and Fisheries. (2019). Prospects and opportunities for Agriculture fish and food investment. Sultanate of Oman. Muscat.

Mishra, A. K., Kumar, A., Joshi, P. K., \& D'souza, A. (2016). Impact of contracts in high yielding varieties seed production on profits and yield: The case of Nepal. Food Policy, 62, 110-121.

Mishra, A. K., Kumar, A., Joshi, P. K., \& D'Souza, A. (2018). Impact of contract farming on yield, costs and profitability in low-value crop: evidence from a low-income country. Australian Journal of Agricultural and Resource Economics, 62(4), 589-607.

North, D. C. (1990). A transaction cost theory of politics. Journal of Theoretical Politics, 2(4), 355367.

Ochieng, D. O., Veettil, P. C., \& Qaim, M. (2017). Farmers' preferences for supermarket contracts in Kenya. Food Policy, 68, 100-111.

Otsuka, K., Nakano, Y., \& Takahashi, K. (2016). Contract farming in developed and developing countries. Annual Review of Resource Economics, 8, 353-376.

Reardon, T., \& Timmer, C. P. (2014). Five inter-linked transformations in the Asian agrifood economy: Food security implications. Global Food Security, 3(2), 108-117. http://doi.org/10.1016/j.gfs.2014.02.001.

Schlecht, S., \& Spiller, A. (2012). A latent class cluster analysis of farmers' attitudes towards contract design in the dairy industry. Agribusiness, 28, 121-134.

Seng, W. K. (2017). The role and importance of the transactions costs theory in agricultural contracting area: an appraisal of selected empirical studies. Journal of Business and Management, 19(1), 79-89.

Schipmann, C., \& Qaim, M. (2011). Supply chain differentiation, contract agriculture, and farmers' marketing preferences: The case of sweet pepper in Thailand. Food policy, 36(5), 667-677.

Tadesse, G., \& Guttormsen, A. G. (2011). The behavior of commodity prices in Ethiopia. Agricultural Economics, 42, 87-97. 
Train, K. (1998). Recreation demand models with taste variation over people. Land Economics, 74(2), 230-239.

Train, K. E. (2009). Discrete choice methods with simulation. Cambridge university press. Retrieved from https://scholar.google.com/scholar?cluster=16561045760721102731\&hl=en\&as sdt=0,5.

Van den Broeck, G., Vlaeminck, P., Raymaekers, K., Velde, K. V., Vranken, L., \& Maertens, M. (2017). Rice farmers' preferences for fairtrade contracting in Benin: Evidence from a discrete choice experiment. Journal of Cleaner Production, 165, 846-854.

Vilbert, V. V., Rajat, P., Shannon, M., Hagerman, C. G., \& Robert, A. K. (2019). Achieving Sustainable Development Goals in the global food sector: A systematic literature review to examine small farmers engagement in contract farming, Business Strategy \& Development, 2(4), 276-289.

Wang, H. H., Wang, Y., \& Delgado, M. S. (2014). The transition to modern agriculture: Contract farming in developing economies. American Journal of Agricultural Economics, 96(5), 1257-1271.

Wang, S., \& van Kooten, G. C. (2018). Forestry and the new institutional economics: An application of contract theory to forest silvicultural investment. Routledge.

\section{Appendices}

Appendix A: Choice cards "Sample"

\begin{tabular}{|c|c|c|c|c|}
\hline Attributes & Option 1 & Option 2 & Option 3 & Option 4 \\
\hline Type of Partner & $\begin{array}{c}\text { Farmer's } \\
\text { organization }\end{array}$ & Processing Firm & Retailing firm & \multirow{7}{*}{$\begin{array}{l}\text { None } \\
\text { of } \\
\text { these }\end{array}$} \\
\hline Cropping Decision Rights & $\begin{array}{l}\text { Farmer's } \\
\text { organization }\end{array}$ & $\begin{array}{c}\text { Farmer's } \\
\text { organization }\end{array}$ & Individually & \\
\hline Quality specification & $\begin{array}{l}\text { Variable } \\
\text { quality } \\
\text { requirement }\end{array}$ & $\begin{array}{l}\text { Highly quality } \\
\text { standards }\end{array}$ & $\begin{array}{l}\text { Minimum quality } \\
\text { requirement }\end{array}$ & \\
\hline Technical assistance & $\begin{array}{l}\text { Provision by } \\
\text { the buyer firm }\end{array}$ & $\begin{array}{l}\text { Provision by the } \\
\text { buyer firm }\end{array}$ & $\begin{array}{l}\text { Provision by the } \\
\text { government }\end{array}$ & \\
\hline Length of contract & $\begin{array}{c}\text { Duration of } \\
\text { contract } 1 \text { year }\end{array}$ & $\begin{array}{c}\text { Duration of } \\
\text { contract } 2 \text { years }\end{array}$ & $\begin{array}{l}\text { Duration of contract } \\
\text { one season }\end{array}$ & \\
\hline Price & Market price & $\begin{array}{l}7 \% \text { more than } \\
\text { market price }\end{array}$ & $\begin{array}{l}\text { 7\% less than market } \\
\text { price }\end{array}$ & \\
\hline $\begin{array}{l}\text { please put tick on your } \\
\text { choice }\end{array}$ & & & & \\
\hline
\end{tabular}

Appendix B: Description of beta regression variables

\begin{tabular}{|c|c|}
\hline Variable & Description \\
\hline Region & $\begin{array}{l}0=\text { if the farmer is from the Al Batinah Region and, } 1=\text { if the farmer is from } \\
\text { AlDakiliha ( interior region ) }\end{array}$ \\
\hline Gender & $0=$ if farmers is female, $1=$ if the farmer is male. \\
\hline Low education & $\begin{array}{l}\text { This variable is coded if } 1 \text { the farmer education attainment level is primary, } \\
\text { intermediary, otherwise is } 0\end{array}$ \\
\hline Medium education & $\begin{array}{l}\text { This variable is coded } 1 \text { if the farmer education attainment level is } \\
\text { secondary or diploma, otherwise is } 0\end{array}$ \\
\hline High education & This variable is coded 1 if the farmer reveals a high education of university \\
\hline
\end{tabular}




\begin{tabular}{|c|c|}
\hline & and above. \\
\hline Age & This variable is continuous and indicates the farmer's age in years. \\
\hline Family size & $\begin{array}{l}\text { This variable is continuous and represents how many children the farmer } \\
\text { has. }\end{array}$ \\
\hline Main job & This variable is coded as $=1$ if the main job is farming, otherwise is $=0$. \\
\hline Low income & $\begin{array}{l}\text { This variable is coded as } 1 \text { if the income range between } 100 \text { to } 600 \text {, } \\
\text { otherwise is } 0\end{array}$ \\
\hline Medium income & $\begin{array}{l}\text { This variable is coded as } 1 \text { if the income range between } 600-2000 \text {, } \\
\text { otherwise is } 0\end{array}$ \\
\hline High income & This variable is coded as 1 if the farmer's income is higher than 2000 OMR. \\
\hline $\begin{array}{l}\text { Marketing } \\
\text { experience }\end{array}$ & $\begin{array}{l}\text { This variable is continuous to represent how many experience years the } \\
\text { farmer has in marketing. }\end{array}$ \\
\hline Land ownership & This variable is coded if farmers own his land as 1 , otherwise is coded as 0 \\
\hline Low operated land & $\begin{array}{l}\text { This variable is coded if the operated land range is less than 5.0, otherwise } \\
\text { is }=0\end{array}$ \\
\hline $\begin{array}{l}\text { Medium operated } \\
\text { land }\end{array}$ & $\begin{array}{l}\text { This variable is coded if the operated land range is between } 5.0-19.9 \\
\text { Feddan, otherwise is }=0\end{array}$ \\
\hline Large operated land & $\begin{array}{l}\text { This variable is coded as } 1 \text { if the operated land Large }>=20.0 \text { Feddan, } \\
\text { otherwise is }=0\end{array}$ \\
\hline Inherited land & This variable is coded as 1 if the land is inherited, otherwise is 0 \\
\hline Rented land & This variable is coded as 1 if the land is rented, otherwise is 0 \\
\hline Shared land & $\begin{array}{l}\text { This variable is coded as } 1 \text { if the land is shared with another partner, } \\
\text { otherwise is } 0\end{array}$ \\
\hline Purchased land & This variable is coded as 1 if the land is purchased, otherwise is 0 \\
\hline Government land & This variable is coded as 1 if the government grants the land, otherwise is 0 \\
\hline $\begin{array}{l}\text { Low cultivated } \\
\text { vegetables }\end{array}$ & This variable is coded as 1 if the cultivated vegetables is $<5.0$ ton \\
\hline $\begin{array}{l}\text { High cultivated } \\
\text { vegetable }\end{array}$ & This variable is coded as 1 if the cultivated vegetables is $<20$ ton \\
\hline
\end{tabular}

